\title{
JILBAB SEBAGAI IDENTITAS ORGANISASI ISLAM DI PERGURUAN TINGGI
}

\author{
Qowim Musthofa \\ Institut Ilmu Al-Qur'an (IIQ) An-Nur \\ Komplek Pon. Pes. An Nur Ngrukem Pendowoharjo, Sewon, Bantul, Yogyakarta, Indonesia \\ E-mail: qowimmusthofa@ymail.com
}

\begin{abstract}
This article was written based on research into jilbab (veil) wearing practices in the Muslim Student Organization KAMMI (Indonesian Muslim Student Action Unit), IMM (Muhammadiyah Student Organization), and KMNU (Nahdlatul Ulama Student Family) Yogyakarta. This study uses qualitative methods by conducting in-depth interviews. The approach is psychological-phenomenological. The principal argument of this study, the veil is used not only the theological issues and commitment to the organization, but also because of the search process that is influenced by psychological aspects.It finds that wearing of the jilbab is a process of identity formation, with individual students being influenced by their intellectualdevelopment, accumulated experiences, and psycho-social situation.
\end{abstract}

\section{Keywords:}

Identity; Islam; organization; veil; student.

\begin{abstract}
Abstrak
Artikel ini ditulis berdasarkan penelitian tentang jilbab pada mahasiswa KAMMI (Kesatuan Aksi Mahasiswa Muslim Indonesia), IMM (Ikatan Mahasiswa Muhammadiyah) dan KMNU (Keluarga Mahasiswa Nahdlatul Ulama) di Universitas Gajah Mada Yogyakarta. Kajian ini menggunakan metode kualitatif dengan melakukan wawancara mendalam. Adapun pendekatannya adalah psikologis-fenomenologis. Pokok argumentasi dari kajian ini, jilbab digunakan tidak hanya persoalan teologis dan komitmen terhadap organisasi, namun juga karena adanya proses pencarian yang dipengaruhi oleh aspek-aspek psikologis. Dari kajian ini ditemukan bahwa jilbab merupakan proses pencarian jati diri, dan persoalan eksistensi-identitas yang dipengaruhi oleh perkembangan intelektual, pengalaman yang terakumulasi dan dipengaruhi oleh psiko-sosial dari masing-masing individu.
\end{abstract}

\section{Kata Kunci:}

Identitas; Islam; Jilbab; mahasiswa; organisasi.

DOI: $10.15575 / \mathrm{jw} . v 2 \mathrm{i} 2.1680$

Received: October 2017; Accepted: December 2017; Published: December 2017 


\section{A. PENDAHULUAN}

Salah satu fenomena masyarakat muslimah di Indonesia adalah tren pemakai jilbab yang semakin bertambah dari tahun ke tahun, terutama di kalangan pelajar dan mahasiswa. Menurut Jamil, jilbab mengalami pertentangan di masyarakat pada era 1980-1990-an, sehingga menyebabkan pemerintah ikut andil dengan mengeluarkan SK No. 100 tahun 1991 yang intinya memperbolehkan penggunaan jilbab di setiap lembaga pendidikan. ${ }^{1} \mathrm{SK}$ tersebut menjadi landasan berpijak bagi masyarakat muslim untuk mengenakan jilbab, terutama di lembaga-lembaga pendidikan.

Yogyakarta merupakan kota pelajar yang di dalamnya terdapat berbagai perguruan tinggi, kampus Universitas Gajah Mada misalnya, yang selanjutnya pada artikel ini akan disebut sebagai UGM saja. Terkait dengan jilbab, di kampus UGM menurut Smith Hefner pada tahun 1970-an kurang dari 3\% muslimah menggunakan jilbab, namun pada tahun 19912001 dan 2002, pengguna jilbab sudah meningkat drastis hingga mencapai $60 \%{ }^{2}$ Peneliti tidak menemukan data paling mutakhir terkait pengguna jilbab secara kuantitatif di perguruan tingi tersebut.

Meski demikian, prosentase yang Begitu signifikan di lingkungan perguruan tinggi tentu didasari dari berbagai faktor yang melatarbelakanginya. Sejauh pengamatan penulis, studi yang dilakukan oleh Anas memberikan kesimpulan bahwa jilbab dapat membentuk identitas keislaman dan ideologi tertentu, baik secara individu maupun kolektif. ${ }^{3}$ Pada pene-

\footnotetext{
${ }^{1}$ Dadi Ahmadi and Nova Yohana, "Konstruksi Jilbab Sebagai Simbol Keislaman," MediaTor (Jurnal Komunikasi) 8, no. 2 (December 29, 2007), 235, http://ejournal.unisba.ac.id/index.php/mediator/article/vi ew/1155.

${ }^{2}$ Nancy J. Smith-Hefner, "Javanese Women and the Veil in Post-Soeharto Indonesia," The Journal of Asian Studies 66, no. 2 (May 26, 2007): 390, doi:10.1017/S0021911807000575.

${ }^{3}$ Anas Shoffa'aul Jannah, "Konstruksi Identitas Kolektif Perempuan Gerakan Salaf (Studi di Masjid Ibnu Sina Fakultas Kedokteran UGM Yogyakarta)," Jurnal Sosiologi Agama 5, no. 2 (2013): 41-54, http://ejournal.uin-
}

litian tersebut, Anas lebih fokus terhadap identifikasi jilbab secara kolektif bahwa individu adalah bagian integral dari organisasi yang bisa merepresentasikan sebuah identitas gerakan.

Selain Anas, studi paling mutakhir terkait eksistensi jilbab di perguruan tinggi dilakukan oleh Turmudi tahun $2016,{ }^{4}$ ia mengungkapkan bahwa penyebarluasan jilbab pada kampus jauh lebih efektif ketika melibatkan mahasiswa di ruang-ruang diskusi organisasi yang berada di kampus. Pada penelitian tersebut, Turmudi menegaskan bahwa jilbab merupakan salah satu media dakwah bagi organisasi perempuan di perguruan tinggi.

Studi selanjutnya dilakukan oleh Eveline Ramadhani pada tahun 2017 yang menyimpulkan bahwa pengguna jilbab yang menjamur di perguruan tinggi mempunyai identitas-identitas tertentu bagi masing-masing organisasi sekaligus dapat dimaknai sebagai representasi simbolis dalam pergaulan dan konsolidasi gerakan-gerakan yang ada di perguruan tinggi. Lebih jauh dari penelitian tersebut, ia mematahkan thesis Batkorwski dan Read di tahun 2000 yang mengatakan bahwa penggunaan jilbab adalah bentuk opresi gender terhadap perempuan, sedangkan Eveline menunjukkan bahwa jilbab adalah suatu kebebasan dan modernitas bentuk baru. ${ }^{5}$ Selain itu, studi yang dilakukan oleh Besse Risnayanti juga memberikan penjelasan yang signifikan bahwa jilbab dapat dijadikan sebagai simbol komunikasi yang berkaitan erat dengan budaya dan ideologi tertentu. ${ }^{6}$

suka.ac.id/ushuluddin/SosiologiAgama/article/view/117 7.

${ }^{4}$ Endang Turmudi, "The Passion of Jilbab : SocioCultural Transformation of Indonesian Muslim Women," International Journal of Scientific and Research Publications 6, no. 5 (2016): 287.

${ }^{5}$ Eveline Ramadhini, "Jilbab Sebagai Representasi Simbolik Mahasiswi Muslim Di Universitas Indonesia," MASYARAKAT: Jurnal Sosiologi 22, no. 1 (Januari 28, 2017)104, doi:10.7454/mjs.v22i1.6835.

6 Besse Risnayanti and Hafied Cangara, "Jilbab Sebagai Simbol Komunikasi Di Kalangan Mahasiswa Universitas Hasanuddin (Studi Komunikasi Nonverbal)," Jurnal Kareba 1, no. 2 (2011), 151. 
Terkait dari beberapa studi di atas, setidaknya terdapat dua hal yang belum ditekankan pada penelitian sebelumnya. Pertama, jilbab bukan semata-mata pakaian fisik yang berfungsi untuk menutup aurat perempuan, melainkan dipengaruhi oleh cara dan gaya berjilbab yang sedang menjadi trend-setter. Kedua, jilbab dipahami sebagai fenomena pakaian psikologis, sebab menggunakan jilbab bukan semata-mata agar dipandang sama dengan anggota kelompok yang diikuti, tetapi juga sikap aktualisasi diri terhadap pemahaman yang dimiliki oleh seseorang.

Oleh karena dua hal tersebut, penulis di sini lebih memfokuskan jilbab dalam konteks identitas secara psikologis dari organisasi mahasiswa Islam di kampus UGM. Hal ini karena di kampus UGM terdapat organisasi mahasiswa Islam yang beragam, namun yang mempunyai pengaruh cukup signifikan adalah KAMMI (Kesatuan Aksi Mahasiswa Muslim Indonesia), organisasi ini mampu menguasai jabatan-jabatan politis di tingkat universitas. Terkait dengan jilbab, dimungkinkan adanya identitas tertentu dalam cara memakai sekaligus modelnya, oleh karenanya sebagai perbandingan, organisasi Islam yang lain di UGM seperti KMNU (Keluarga Mahasiswa Nahdlatul Ulama) dan IMM (Ikatan Mahasiswa Muhammadiyah) juga mempunyai identitas tertentu dalam persoalan jilbab. Oleh karena itu, penelitian ini bertumpu pada sisi-sisi psikologis dalam model-model jilbab dan pemakaiannya yang dimungkinkan mempunyai representasi identitas tertentu dari setiap organisasi mahasiswa Islam di kampus tersebut.

Dari pengamatan penulis, terdapat tiga model jilbab secara fisik, pertama, menutupi setengah/sebagian dada. Kedua, hanya menutupi rambut kepala, dan ketiga jilbab besar yang menjuntai menutupi dada dan punggung, bahkan lebih panjang dari itu. Ketiga model tersebut dipengaruhi oleh model-model perkembangan fashion.

Dari keterangan di atas memunculkan pertanyaan: mengapa mahasiswi yang ikut berperan di organisasi Islam di UGM menggunakan jilbab dengan variasi yang berbeda-beda?
Apakah muslimah di UGM konsisten dalam menggunakan jilbab dengan model tersebut? Kedua pertanyaan itulah yang setidaknya akan dibahas pada tulisan ini dengan bertumpu pada dua hal: pertama, argumentasi yang dibangun oleh penulis tidak secara teologis, melainkan secara psikologis dari subjek. Kedua, sisi teologis tersebut tidak dipakai sebagai satu-satunya bahan primer untuk mengkaji tentang fenomena jilbab, melainkan hanya sebagai pertimbangan sekunder yang sematamata berfungsi untuk melegitimasi bagi masing-masing organisasi Islam di UGM.

Tulisan ini berdasarkan penelitian yang menggunakan metode kualitatif yang difokuskan pada pemaknaan realitas sosial. Penulis melakukan wawancara mendalam dan observasi terhadap pengguna jilbab di lingkungan UGM. Adapun informan dibagi menjadi tiga, yaitu informan yang menggunakan jilbab berasal dari organisasi Islam KAMMI, KMNU dan IMM yang ketiganya mempunyai komitmen dan loyalitas terhadap masing-masing organisasinya. Penulis juga memberikan syarat minimal berusia 20 tahun, sebab di usia tersebut seorang individu secara psikologis sanggup mengambil tanggung jawab penuh bagi kepercayaan religiusnya sendiri, terlepas dari kelompok atau orang lain yang mendefinisikan hidupnya. ${ }^{7}$ Selain itu, pendekatan yang dilakukan dalam penelitian ini adalah pendekatan psikologis-fenomenologis sebagai kaca mata dalam melihat fenomena jilbab di perguruan tinggi. Hasil dari pencarian data akan diurai secara deskriptif-analitis-deduktif. Adapun motode triangulasi juga dilakukan dalam rangka mencari validitas data yang ditemukan kemudian didukung oleh literaturliteratur yang telah dikaji sebelumnya terhadap penelitian ini. Penelitian ini dilakukan di Universitas Gajah Mada (UGM) sebagai studi kasus fenomena jilbab sebagai identitas organisasi Islam di Perguruan Tinggi.

Juneman, Psychology of Fashion: Fenomena Perempuan [Melepas] Jilbab, (Yogyakarta: Pustaka Pelajar, 2011), 94. 


\section{Jibab: Dari Tafsir Klasik Hingga Kon- temporer}

Jilbab, tidak dipungkiri mempunyai aspek teologis, sebab di dalam Alquran dan sunnah sudah tertulis jelas terkait persoalan jilbab di dalam surat al-Ahzab: 59, kendati Alquran membicarakan jilbab dalam kadar pembahasan yang global (mujmal), sebab di sana tidak dijelaskan tentang model jilbab (style), dan batasan-batasan jilbab secara lebih spesifik, apakah menjuntai sampai ke seluruh tubuh, atau betis, pantat, atau hanya cukup menutupi rambut dan dada. Oleh karenanya jawaban pertanyaan demikian hanya bisa ditemukan di literatur-literatur tafsir, dan secara lebih detail lagi pada ilmu fikih.

Para mufassir klasik hingga pertengahan, misalnya Imam at-Thabari (839-923 M) dalam tafsirnya menjelaskan tentang ayat jilbab tersebut lebih praktis dengan menyebutkan alasan secara fungsional. Ia menegaskan bahwa jilbab berfungsi sebagai pembeda antara perempuan merdeka dan budak. Apabila perempuan keluar dari rumah hendaknya memanjangkan jilbabnya supaya orang fasik tidak berani menganggungnya. Jilbab yang sesuai dengan syariat harus menutupi seluruh tubuh dan menyisakan kedua mata. ${ }^{8}$ Imam alQurtubi (1204-1273 M) menjelaskan jilbab lebih konseptual bahwa definisi jilbab yang paling tepat adalah pakaian perempuan yang menutupi seluruh tubuhnya, bahkan hingga tidak ada kulit yang terlihat. ${ }^{9}$ Senada dengan hal itu, Ibnu Katsir (1301-1371 M.) dalam tafsirnya juga menjelaskan bahwa jilbab adalah rida' (sejenis gamis) yang digunakan di atas khimar (sejenis kerudung penutup rambut kepala). ${ }^{10}$

Sedangkan beberapa pendapat kontemporer terkait ayat tentang jilbab, cenderung lebih

\footnotetext{
${ }^{8}$ Muhammad Ibn Jarir At-Thabari, Jami'ul Bayan Fi Ta'wil Al-Qur'an, vol. 20 (Beirut: Muassasati arRisalah, 2000), 324.

${ }^{9}$ Syamsuddin Al-Qurtubi, Tafsir Al-Qurthubi (t.k.: Maktabah Syamela, t.th.), 242-243.

Syamsuddin al-Qurtubi, Tafsir al-Qurthubi, Vol. 14, 242-243 Maktabah Syamela

${ }^{10}$ Ibnu Katsir, Tafsir Al-Qur'an Al-'Adhim (t.k.: Maktabah Syamela, t.th.), 481.
}

longgar dalam memaknai jilbab sebagai pakaian penutup perempuan. Misalnya, Qasim Amin (1803-1908 M.) ia dijuluki sebagai Pembebas Perempuan (Muharrir al-Mar'ah) salah satu pendapatnya terkait pakaian perempuan adalah tentang jilbab, ia menegaskan bahwa tidak ada ketetapan agama yang bersumber dari Alquran yang mewajibkan pakaian khusus terhadap perempuan (hijab, jilbab, dan lain-lain) semua pakaian itu adalah hasil dari kebudayaan dan tradisi Arab dan sekitarnya, ia juga berpendapat bahwa secara syariat Islam, perempuan boleh menampakkan sebagian dari tubuhnya kepada mahramnya, namun Alquran tidak secara tegas bagian mana yang boleh ditampakkan itu. ${ }^{11}$ Selain itu, pandangan Syahrur juga penting untuk dijelaskan di sini, bahwa dalam kesimpulannya ia menjelaskan pakaian tertutup perempuan bukanlah hasil yang diproduksi dari teks agama, melainkan hasil dari akulturasi dan pengaruh-pengaruh budaya dari Arab dan sekitarnya yang, dianggap baik oleh masyarakat pada saat itu, kemudian dijadikan sebagai standar moral, oleh karenanya jilbab bisa berubah-ubah sesuai dengan kondisi dan zaman suatu kebudayaan masyarakat tertentu. ${ }^{12}$

Terkait pendapat mufasir klasik dan cendekiawan kontemporer di atas, Quraish Shihab memberikan argumentasi secara adil dalam menyikapi perbedaan pendapat terkait bagianbagian tubuh perempuan yang harus ditutup. Ia menyimpulkan bahwa ayat Alquran yang berbicara tentang pakaian perempuan mengandung aneka interpretasi, Begitu pula hadishadis yang dijadikan rujukan, para ulama dan cendekiawan mempunyai aneka pertimbangan yang tidak bisa diseragamkan, oleh karenanya mengatakan perbedanaan pendapat dalam persoalan jilbab bukanlah sebuah sikap berlebihan, melainkan keniscayaan yang seharusnya tidak perlu dikonfrontasikan, melainkan disi-

\footnotetext{
11 Qasim Amin, Tahriru Al-Mar'ah (Mesir: Zaky ad-Din, 1347 H.), 54-58.

12 Muhammad Syahrur, Nahwa Ushul Jadidah Li Al-Fiqh Al-Islam (Beirut: al-Hali, 2002), 356.
} 
kapi dengan proposional sesuai dengan semangat Islam yang meniscayakan keberbedaan. ${ }^{13}$

Dari beberapa pendapat di atas, penulis tidak hendak menjustifikasi kebenaran dan kesalahan dari masing-masing pendapat atau bahkan men-tarjih. Penulis hanya ingin memberikan gambaran bahwa dalam persoalan jilbab, bukan semata-mata persoalan teologis yang sarat dengan dalil Alquran dan hadis, tetapi juga persoalan sosial-budaya yang erat kaitannya dengan identitas individu secara psikologis. Oleh karenanya, selanjutnya penulis akan memaparkan persoalan jilbab sebagai pakaian yang dapat merepresentasikan secara psikologis.

\section{Jilbab sebagai Pakaian Psikologis}

Jilbab sebagai fenomena sosial juga dapat memberikan kesan atau dapat menjadi simbol komunikasi antara subjek lingkungan socialnya. Dalam persoalan ini, Juneman dalam penelitiannya memberikan penjelasan yang baik atas fenomena jilbab secara psikologis. Ia mengungkapkan dari beberapa sumber bahwa dalam bahasa inggris kata fashion dan clothes mempunyai arti yang berbeda. Fashion adalah gaya, mode, cara dalam berpakaian, yang bersifat psikososiokultural (subtantif, melibatkan gagasan eksistensial, serta berasal dari internal pribadi pemakainya), sedangkan clothes adalah materialnya, fisiknya yang mempunyai kesamaan arti dengan kata textile, garment, fabric, dan dress. ${ }^{14}$

Hal tersebut diafirmasi oleh Quraish Shihab yang menyatakan bahwa pakaian dapat memberikan dampak secara psikologis terhadap pemakai dan yang melihatnya. ${ }^{15}$ Begitu pula Ubaydillah dalam tulisannya menyatakan bahwa busana bisa dikatakan bagian dari simbol yang dapat menjelaskan identitas diri sese-

13 Quraish Shihab, Jilbab Pakaian Wanita Muslimah: Pandangan Ulama Masa Lalu Dan Cendekiawan Kontemporer (Jakarta: Lentera Hati, 2014), 247-250.

14 Juneman, Psychology of Fashion: Fenomena Perempuan [Melepas] Jilbab, 21.

15 Sihab, Jilbab pakaian wanita Muslimah: Pandangan Ulama Masa Lalu \& Cendekiawan Kontemporer, 202. orang. Pendapat yang lebih jauh menjelaskan juga bahwa pakaian tidak hanya menciptakan, tetapi juga dapat mengubah identitas yang membawa pada transformasi diri, baik secara fisik maupun mental. Bahkan sekalipun efeknya sementara, namun efek fashion semacam ini tidak dimiliki oleh semua orang. Beberapa orang tidak menginginkan pakaiannya lebih dari dari sekadar kenyamanan dan kemampuan untuk beradaptasi dengan ragam fungsi dan aktivitas. $^{16}$

Mengikuti beberapa pendapat di atas, penulis membedakan jilbab sebagai material bentuk pakaian, dan jilbab sebagai gaya, mode, dan cara (berjilbab). Pembedaan ini menjadi penting sebab jilbab bukan semata-mata pakaian yang berfungsi menutup sebagian anggota tubuh perempuan, melainkan juga dapat merepresentasikan kepribadian seseorang. Yakni bagaimana seseorang memakai jilbab, dengan motif seperti apa, bentuk dan gaya yang bagaimana dan lain seterusnya. Hal-hal seperti demikianlah yang, secara psikologis akan dielaborasi lebih lanjut dalam tulisan ini.

Selain itu, jilbab sebagai fashion juga mempunyai sisi-sisi yang paradoks. Pertama, jilbab bisa digunakan untuk memberikan kesan (to impress) yang secara tidak langsung menjelaskan "saya muslimah", dan di sisi lain untuk memberontak atau melawan (to rebel) sesuatu yang dianggap lebih kuat. Kedua, jilbab dapat digunakan untuk menyatakan sikap penyesuaian terhadap komunitas atau kelompok, dan di sisi lain untuk menyatakan sikap bertahan atau memegang teguh pendirian, sebagaimana yang terjadi di Iran pada tahun 1970-an bahwa jilbab dijadikan sebagai simbol kebajikan yang merepresentasikan perempuan muslimah Iran untuk melawan kaum Pahlevis dengan undang-undang dan gerakan westernisasinya. ${ }^{17}$

Penjelasan di atas dapat dijadikan sebagai argumentasi bahwa jilbab tidak bersifat statismonoton. Jilbab lebih besar fungsinya sebagai

\footnotetext{
16 Juneman, Psychology of Fashion: Fenomena Perempuan [melepas] jilbab, 22-23.

17 Fedwa El Guindi, Jilbab: Antara Kesalehan, Kesopanan Dan Perlawanan (Jakarta: Serambi Ilmu Semesta, 2004), 277.
} 
media untuk mencoba mendefinisikan diri sendiri sebagai subjek sekaligus mengkomunikasikannya dengan sesuatu yang lain di luar diri subjek, bisa individu yang lain atau kelompok tertentu. Dengan hal ini jilbab bisa berubah dalam hal bentuk fisik maupun modelnya, tentu dalam hal model atau gaya berpakaian itu berevolusi dan dapat menunjukkan adanya koneksi antara dunia pengalaman masa lalu, masa kini hingga masa depan yang selalu berkesinambungan dengan perkembangan individu. $^{18}$

Berkaitan dengan perkembangan individu, Fowler menggunakan istilah faithing yang menjelaskan secara fenomenologis bahwa faithing is what faith does, pengertian semacam ini bersifat meniscayakan proses yang penuh dinamika, perkembangan, pertumbuhan dan kemajuan. Ia juga menjelaskan bahwa faithing adalah an active mode of knowing, of composing a felt sense or image of the condition of our lives taken as a whole. It unifies our lives force field. Jadi, perkembangan kepercayaan yang dialami oleh seseorang dapat dipastikan adanya pengaruh atau sensitifitas terhadap lingkungan yang meniscayakan adanya perubahan dan kemajuan. ${ }^{19}$

\section{Konsep Identitas Sosial dalam Fenomena Jilbab di Perguruan Tinggi}

Peter Berger dan Luckmann di dalam bukunya Tafsir Sosial Kenyataan mengungkapkan bahwa identitas adalah sebuah unsur kunci dari kenyataan subyektif yang secara langsung berhubungan dengan masyarakat secara dialektif. Identitas dibentuk oleh proses-proses sosial. Begitu ia memperoleh wujudnya (pola identitasnya), ia dibentuk, dipelihara, dimodifikasi, bahkan dibentuk ulang oleh hubunganhubungan sosial. Sedangkan, proses sosial yang terlibat dalam membentuk dan mempertahankan identitas juga ditentukan oleh struktur sosial, dan struktur sosial juga dibentuk oleh sejarah manusia (kebudayaan)

18 Juneman, Psychology of Fashion: Fenomena Perempuan [melepas] jilbab, 26.

19 Juneman, Psychology of Fashion: Fenomena Perempuan [melepas] jilbab, 69-71. itu sendiri yang, tidak menafikan identitas masing-masing individu dengan identitas tertentu. Dengan demikian penulis menyimpulkan bahwa di balik identitas sosial, terdapat identitas tertentu yang bersifat parsial. ${ }^{20}$

Istilah yang harus dijauhi -masih menurut Berger dan Luckman- adalah identitas kolektif, sebab istilah tersebut akan menjebak sekaligus tidak memperhitungkan keunikan dari eksistensi individu. "Struktur-struktur sosial historis tertentu melahirkan tipe-tipe identitas, yang bisa dikenali dalam kasuskasus individual." Berger dalam hal ini menegaskanbahwa kasus-kasus individual itu lebih spesifik dan berkaitan dengan aspek psikologis. Dengan demikian jilbab menjadi identitas sosial sangat berkaitan dengan suatu dimensi dari kenyataan yang mempunyai relevansi subyektif paling besar dan paling sinambung bagi semua individu. ${ }^{21}$

\section{B. HASIL DAN PEMBAHASAN}

Berkaitan dengan beberapa poin yang telah dijelaskan di atas, ketika penulis melakukan wawancara dengan informan di perpustakaan UGM, penulis mengamati beberapa mahasiswi yang berjilbab dengan bentuk yang beragam, secara lebih spesifik penulis memberikan pola-pola dan tipifikasi terhadap pemakai jilbab. Pertama, individu yang memakai jilbab cenderung kecil, yakni hanya menutupi setengah dada, biasanya motif dari jilbab ini berwarna-warni dan penuh hiasan disertai dengan bros dan pin tertentu yang berfungsi untuk menaikkan salah satu sisi jilbab ke salah satu bahu, tipe pertama ini pun terbagi dua, yakni memakai celana, baik ketat maupun agak longgar, dan memakai rok.

Kedua, individu yang memakai jilbab agak besar, yakni menjulur sampai ke dada, punggung dan lengan, baik dengan model jilbab

20 Peter Berger, Tafsir Sosial Atas Kenyataan: Risalah Tentang Sosiologi Pengetahuan (Jakarta: LP3ES, 2013), 235-237.

${ }^{21}$ Berger, Tafsir Sosial Atas Kenyataan: Risalah Tentang Sosiologi Pengetahuan, 239. 
langsung, ${ }^{22}$ maupun jilbab persegi yang mengharuskan pemakainya untuk melipatnya terlebih dahulu sebelum memakai. Para pemakai jilbab dengan model demikian, sejauh pengamatan penulis adalah memakai rok panjang dan longgar. Jilbab model kedua ini masih tampak motif-motif jilbab yang bervariasi, mulai dari bunga-bunga yang menghiasi jilbab, renda-renda di ujung jilbab dan lubanglubang kecil di sisi jilbab.

Ketiga, individu yang memakai jilbab besar dan panjang yang menutupi bawah dada dan pantat, bahkan ada yang lebih panjang dari itu. Sesekali terlihat tipe ketiga ini memakai cadar untuk menutupi wajah yang menyisakan kedua mata. Pada model yang ketiga ini, sejauh pangamatan penulis, tidak mendapati model warna-warni dan motif-motif yang dimiliki oleh tipe pertama dan kedua. Model ketiga ini lebih cenderung menggunakan satu warna polos saja dalam model jilbab.

Dari identifikasi dan tipifikasi yang penulis lakukan di atas, penulis menyimpulkan bahwa model yang kedua dan ketiga itulah yang mencirikan identitas tertentu dalam suatu kelompok/komunitas. Adapun model yang pertama secara kasat mata menyiratkan secara sederhana bahwa ia adalah muslimah. Kesimpulan ini tentunya dengan beberapa pertimbangan dan jauh dari gegabah, meskipun perlu untuk dielaborasi lebih jauh lagi. Namun, Setidaknya penulis akan memberikan ulasan lebih jauh terkait hal tersebut pada sub-bab selanjutnya.

\section{Historisitas Munculnya Organisasi Mahasiswa Islam di Perguruan Tinggi}

Sebagaimana yang menjadi subyek penelitian pada tulisan ini, maka organisasi Islam di kampus UGM yang akan penulis jelaskan terlebih dahulu adalah KAMMI (Kesatuan Aksi Mahasiswa Muslim Indonesia), organisasi ini adalah organisasi pergerakan yang ber-

\footnotetext{
22 Salah satu dari informan mengistilahkan jilbab instan, yakni jilab berlubang yang dipakai untuk memasukkan kepala dan menjulur ke bawah, jilbab seperti demikian "biasanya" dipakai dengan model panjang mulai lengan siku hingga setengah badan yang menutupi hasta.
}

mula atas keprihatinan yang terjadi pada krisis 1998. KAMMI muncul sebagai kekuatan alternatif mahasiswa yang berbasis mahasiswa muslim dengan mengambil momentum pada pelaksanaan forum Silaturahmi Lembaga Dakwah Kampus (FS-LDK) ke Sembilan yang diselenggarakan di Universitas Muhammadiyah Malang pada Maret 1998.

KAMMI itu gerakan ekstra kampus, sejarah sebenarnya bukan tepat didirikan oleh tarbiyah sih, malahan didirikannya oleh anak-anak HMI (Himpunan Mahasiswa Islam-red.), anak HMI yang dia juga terkena pesona-pesona tarbiyah gitu, ya anak tarbiyah, anak liqa' juga... jadi secara manhaj itu ikut ke sana (tarbiyah), atau secara kulturnya juga, mungkin., 23

Penulis tentu tidak akan tergesa mengambil kesimpulan hanya dengan berdasarkan wawancara tersebut, namun dari ungkapan di atas minimal hal tersebut memberikan asumsi yang kuat bahwa tidak memungkiri organisasi KAMMI, ternyata dipengaruhi oleh Tarbiyah baik cara berpikir (manhaj) maupun secara kultural, meskipun besar atau kecilnya pengaruh sangat relatif-subyektif. Namun pengaruh tersebut bisa dimungkinkan sebab secara historis, jamaah Tarbiyah yang muncul di Indonesia pada tahun 1980 sebagai organisasi trans-nasional dari Mesir, mulai melebarkan sayapnya ke berbagai perguruan tinggi umum pada tahun 1998 hingga bertransformasi menjadi partai politik (PK: Partai Keadilan), kemudian mengubah nama pada tahun 2003 menjadi Partai Keadilan Sosial (PKS). ${ }^{24}$

Selain KAMMI, organisasi yang lain adalah IMM (Ikatan Mahasiswa Muhammadiyah). Kelahiran IMM tidak bisa lepas dari sejarah perjalanan Muhammadiyah sebagai salah satu organisasi Islam terbesar di Indonesia

\footnotetext{
${ }^{23}$ Fi (Mahasiswi Geografi kader KAMMI UGM), wawancara oleh Qowim, Perpustakaan UGM, pada 19 September 2017.

24 Disarikan dari diskusi dan wawancara kader KAMMI di UGM pada September 2017 di Perpustakaan UGM. Bandingkan dengan Yon Machmudi, Islamising Indonesia: The Rise of Jemaah Tarbiyah and The Prospereous Justice Party (PKS) (Canberra: Australian National University Press, 2008).
} 
yang didirikan oleh KH. Ahmad Dahlan. Oleh karenanya beberapa bentuk ideologi dan manhaj yang dibangun oleh IMM sebagian besar mengikuti asal muasalnya tersebut. Pada perkembangan selanjutnya, Muhammadiyah menahbiskan diri sebagai organisasi kaum modernis.

IMM didirikan pada 14 Maret 1964, beberapa faktor yang melatarbelakangi lahirnya IMM ini. Pertama sebagai wadah kader-kader Muhammadiyah di beberapa perguruan tinggi sekuler agar tidak terjebak di dunia politik praktis. Kedua, untuk membingkai kader-kader muda Muhammadiyah dari praktik-praktik agama yang bid'ah, takhayul, dan khurafat. ${ }^{25}$

Meski demikian, pada awalnya kemunculan IMM menjadi polemik tersendiri di internal Muhammadiyah, sebab Pemuda Muhammadiyah dan Nasyiatul Aisyiyah masih dianggap cukup mampu untuk mewadahi mahasiswa di kalangan Muhammadiyah. Hal ini cukup beralasan sebab sebagian dari ketua Muhammadiyah, Pemuda Muhammadiyah, Nasyiatul Aisyiyah dan amal usaha Muhammadiyah adalah kader-kader yang dididik dan dibesarkan oleh HMI (Himpunan Mahasiswa Islam). Polemik tersebut mulai mereda ketika Muhammadiyah pada tahun 1956 secara formal melepaskan diri dari Masyumi dan kembali sebagai gerakan Islam amar ma'ruf nahi munkar, hal ini meniscayakan Muhammadiyah tidak harus mengakui satu-satunya gerakan mahasiswa Islam di Indonesia adalah HMI. Dengan demikian, IMM lahir dan menegaskan bahwa IMM adalah gerakan mahasiswa Islam yang menjadikan kepribadian Muhammadiyah sebagai landasan perjuangan IMM. ${ }^{26}$

Seirama dengan hal itu, KMNU (Keluarga Mahasiswa Nahdlatul Ulama) juga berpartisipasi dalam meramaikan kancah gerakan mahasiswa. KMNU secara ideologis lahir di ling-

\footnotetext{
25 Farid Fathoni, Kelahiran Yang Dipersoalkan: Seperempat Abad Ikatan Mahasiswa Muhammadiyah (IMM) 1964-1989 (Jakarta: Bina Ilmu, 1990), 102.

26 Fathoni, Kelahiran yang Dipersoalkan: Seperempat Abad Ikatan Mahasiswa Muhammadiyah (IMM) 1964-1989, 94-98
}

kungan NU yang didirikan oleh KH. Hasyim Asy'ari pada tahun 1926, salah satu faktornya adalah isu internasional masyarakat muslim yang terjadi di Makkah-Madinah. Penguasa baru Hijaz yakni Raja Saud ingin menerapkan asas tunggal Islam dan berencana menghancurkan situs-situs sejarah Islam di Hijaz karena dinilai sebagai perusak ajaran tauhid yang menyebabkan adalah pengkultusan, bahkan kemusyrikan. Pada saat itulah NU didirikan dan mengirimkan KH. Wahab Hasbullah menjadi delegasi kaum Islam di Indonesia. ${ }^{27}$

Sebagaimana kelahiran IMM, kelahiran KMNU pada tahun 1955 pun pada awalnya ditentang oleh kader-kader NU yang tak ingin tersaingi eksistensinya, seperti IPNU dan IPPNU. Meski demikian, karena mantan kader IPNU dan IPPNU yang telah menjadi mahasiswa merasa tidak memiliki wadah untuk bergerak di tataran universitas, maka dibentuklah PMII (Persatuan Mahasiswa Islam Indonesia).

KMNU yang dulunya ada dan hilang kini mulai muncul lagi yang puncaknya pada tahun 2015 melaksanakan Munas Pertamanya di Yogyakarta dengan diikuti oleh $11 \mathrm{KMNU}$ dalam negeri dan $1 \mathrm{KMNU}$ Malaysia dengan kesepakatan didirikanlah KMNU Pusat sebagai koordinator dari KMNU sedunia. Namun, KMNU bukanlah badan otonom yang berada dibawah PBNU. KMNU adalah organisasi yang independen, terbentuk oleh kemauan mahasiswa sendiri yang berfungsi untuk merangkul mahasiswa NU bersama PMII.

Baik KAMMI, IMM, maupun KMNU merupakan varian Mahasiswa Islam yang berkembang di perguruan tinggi, bahkan dapat dikatakan dominan. Di UGM ketiga organisasi tersebut dapat berkembang secara masif dan mempunyai kader-kader yang setiap tahun ikut kaderisasi. Menariknya, ketiga organisasi tersebut secara rutin mengadakan forumforum diskusi, khususnya adalah tentang keperempuanan, baik secara kultural, aksidental

27 Sejarah lebih luas dapat dibaca G.F. Pjiper, Beberapa Studi Tentang Sejarah Islam di Indonesia 1900-1950., diterjemahkan oleh Yessy Augusdin Tudjimah (Jakarta: Universitas Indonesia, 1984). 
maupun terstruktur. Seperti mahasiswa IMM mengadakan forum diskusi sepekan sekali, KMNU mengadakan kegiatan kultural pembacaan shalawat nabi, tahlil dan diskusi internal, Begitu pula KAMMI yang mempunyai wadah daurah yang berjenjang dan liqa' yang secara rutin tentang perempuan di masjid-masjid.

Perbedaan sejarah dari masing-masing kelompok menunjukkan bahwa tiap kelompok mempunyai perbedaan momori kolektif dan mempengaruhi dalam mengintegrasikan paham keberagamaannya pada ranah praktis, sehingga mereka juga mempunyai metode yang berbeda dalam menginternalisasikan pemahaman agamanya, tidak luput pula dalam persoalan jilbab.

Jilbab menjadi persoalan yang tidak biasa, meskipun mayoritas dari hasil wawancara menyatakan bahwa jilbab hukumnya wajib, artinya ketika muslimah tidak memakai jilbab bisa dikatakan belum sempurna kemuslimahannya. Meskipun demikian, batas-batas terkait dengan ukuran jilbab bagi KAMMI, KMNU dan IMM cenderung lebih longgar dan tidak ada kesepakatan tentang batas minimal jilbab, kecuali yang terpenting adalah menutupi dada.

\section{Fenomena Variasi Jilbab di Perguruan Tinggi: Perkembangan Faithing dan Pengaruh Sosial dalam Menemukan Identitas}

Dalam hal perbedaan model berjilbab di UGM, terdapat hal yang menarik ketika penulis wawancara dengan salah satu kader KMNU tentang fenomena jilbab yang kecil dan hanya menutupi sebagian dada. Ia mengungkapkan:

Kalau saya sih terserah (orang yang memakai jilbab kecil) yang penting dia udah mau pake jilbab, udah, ya Alhamdulillah gitu lho dari pada enggak (pakai jilbab), maksudnya setelah itu pasti nanti akan ada fase dalam hidupnya masing-masing. Seseorang itu kan baru menemukan, jadi nanti akan berkembang sendiri menjadi lebih baik. ${ }^{28}$

Ungkapan di atas menunjukkan bahwa adanya perkembangan kepercayaan (faithing) di

\footnotetext{
${ }^{28}$ Pri (Mahasiswi Sastra Arab UGM kader KMNU UGM), wawancara oleh Qowim, 9 September 2017.
}

dalam sebuah perilaku keberagamaan, yakni sebuah tindakan yang secara terus-menerus akan diperbaharui seiring dengan perkembangan penalaran, pengalaman, sekaligus pengamalan dalam beragama. Hal tersebut juga diafirmasi oleh kader IMM yang menjelaskan bahwa ketika masih masuk di semester awal-awal perkuliahan masih memakai jilbab yang ala kadarnya, dan hanya menutupi sebagian dada. Namun setelah sekian lama dan ikut beberapa kegiatan di IMM dan bertambahnya pengetahuan tentang jilbab, kemudian memilih jilbab yang agak besar, yang dapat menutup seluruh dada, punggung serta lengan. ${ }^{29}$ Seirama dengan hal tersebut, kader KAMMI pun mengungkapkan hal yang lebih spesifik terkait jilbab bagi individu:

Emang ada beberapa anak KAMMI yang aku kenal gitu kan, kerudungnya memanjang perlahan, dan sekarang lebih panjang dari pada aku, (tertawa), ya seneng aja ngelihatnya gitu, karena emang lebih dihormati sama sekitarnya, dihargai dan dianya sendiri juga ngerasa emang lebih aman, gitu, karena orang enggak berani godain aneh-aneh lagi, kan. $^{30}$

Ungkapan di atas menunjukkan bahwa jilbab tidak bersifat statis dalam hal bentuk dan modelnya, melainkan sarat dipengaruhi oleh hal-hal subyektif dengan adanya perkembangan pengalaman, pengetahuan, kenyamanan dalam berpakaian dan lain-lain. Beberapa informan juga mengaku bahwa framing media terkait beberapa bentuk jilbab yang modelnya beragam, bagi mereka itu pengaruhnya tidak begitu lama,

Jika kader secara rutin mengikuti kegiatankegiatan di organisasi maka tren jilbab yang beragam itu akan hilang dengan sendirinya dan ia akan kembali lagi memakai jilbab yang seperti biasanya, minimal pan-

\footnotetext{
${ }^{29}$ Ay (MahasiswiAgrobisnis Sosial Ekonomi Kader IMM UGM), wawancara oleh Qowim, Perpustakaan UGM, 12 September 2017.

${ }^{30} \mathrm{Ni}$,(Mahasiswi Psikologi kader KAMMI UGM), Perpustakaan UGM, tanggal 9 September 2017.
} 
jangnya sampai dada, melingkar ke lengan dan punggung. ${ }^{31}$

Dari keterangan di atas, menurut Fowler perkembangan kepercayaan (faithing) yang dialami oleh seseorang merupakan pengaruh sekaligus adanya sensitifitas terhadap lingkungan. Artinya, jilbab bukan sebuah pakaian instan yang dipakai secara ahistoris, jilbab adalah proses menemukan jati diri, kesesuaian, bahkan kenyamanan bagi pemakainya yang tidak bisa terlepas dari kondisi sosio-historis dan latar belakang wawasan ilmu yang dimiliki. Lebih dari itu, jilbab juga termasuk cara untuk berkomunikasi dengan komunitas dan lingkungan sosialnya, baik untuk memberikan kesan, menjaga diri, dan lebih terhormat.

Dalam persoalan pengaruh sosial, mayoritas informan menerangkan bahwa memilih salah satu organisasi Islam di kampus dikarenakan secara kultural mereka di besarkan oleh tradisi tertentu yang mempunyai afiliasi dengan organisasi Islam tersebut. Sebagaimana KMNU, kader-kader yang mengikuti kegiatan KMNU mayoritas dibesarkan oleh orang tua atau lembaga yang mempunyai afiliasi kuat dengan NU, Begitu pula kader IMM yang secara kultural juga dibentuk oleh orang tua yang Muhammadiyah atau sekolah di Muhammadiyah. Sedangkan KAMMI, lebih cenderung menampung masa dari kader-kader yang sudah sejak di SMA mengikuti organisasi Rohis (Rohani Islam), meskipun tidak punya kesepakatan dengan KAMMI secara organisatoris, namun secara ideologis-kultural sudah menjadi kesepakatan bersama, seolah menyimpulkan bahwa keberlanjutan Rohis di Kampus adalah KAMMI. $^{32}$ Jadi ketiga organisasi tersebut memang menjadi wadah keberlanjutan bagi mahasiswa, baik secara kultural maupun organisatoris.

31 Ni dan $\mathrm{Nu}$ (Mahasiswi Peternakan, kader KAMMI UGM), Perpustakaan UGM, tanggal 09 September 2017.

32 Fi (Mahasiswi jurusan Geografi UGM kader KAMMI) wawancara oleh Qowim, pada 9 September 2017.
Meskipun demikian, hal yang harus ditinjau kembali adalah bagaimana persoalan jilab tersebut kemudian menjadi sebuah identitas bagi ketiga organiasasi tersebut? Menjawab pertanyaan ini juga harus teliti dan hati-hati, sebab sepanjang pengamatan penulis, jilbab sebagai identitas organisasi mahasiswa juga mempunyai polemik tersendiri.

Jilbab sebagai identitas bagi organisasi Islam di perguruan tinggi mempunyai beberapa tingkatan, artinya setiap pemakai jilbab tidak hanya memakai satu bentuk model jilbab saja. Mereka cenderung membedakan jilbab yang dikenakan sehari-hari dan jilbab yang dikenakan pada acara-acara resmi. Pada umumnya mereka menggunakan jilbab instan pada kebiasaan sehari-hari, seperti ketika mencuci baju, masak, pergi ke warung, ke perpustakaan dan belanja, sedangkan mereka memakai jilbab yang persegi berlipat ketika pada acaraacara resmi seperti kuliah, seminar, menemui dosen, dan lain-lain. ${ }^{33}$

Hal tersebut menunjukkan bahwa jilbab bukan hanya sekedar pakaian yang berfungsi sebagai penutup, melainkan juga bisa merepresentasikan kedirian seseorang sebagai cara berkomunikasi dengan kebiasaan yang sudah terstruktur secara psikologis maupun sosiologis. Meskipun mereka tidak punya aturan khusus dalam berjilbab, namun hal itu sudah menjadi kebiasaan.

Selain itu, para informan juga cenderung membedakan jilbab ketika sedang berkumpul dengan komunitas organisasinya. Kader IMM yang pada hari-hari biasa mengenakan jilbab yang kecil dan memakai celana, ketika menghadiri acara-acara ke-Muhammadiyah-an mereka cenderung memanjangkan jilbabnya. Sebagaimana ungkapan kader IMM "ada yang biasanya pake jilbab kecil, tapi mereka bisa menyesuaikan, ketika mereka kumpul sama kami, ya jilbabnya agak di-ini-in (dibe-

\footnotetext{
${ }^{33}$ Di (Mahasiswi Pertanian UGM kader KMNU) wawancara oleh Qowim, pada 19 September 2017. Ay (Mahasiswi jurusan Agrobisnis Ekonomi Pertanian UGM kader IMM) wawancara oleh Qowim, pada 12 September 2017.
} 
sarkan dan dipanjangkan sampai lengan) ${ }^{, 34}$ hal tersebut menunjukkan bahwa organisasi secara tidak langung dapat memengaruhi cara berjilbab seseorang sekaligus menunjukkan komitmen serta loyalitas bagi organisasi yang diikuri. Tidak hanya IMM, kader KAMMI pun mengungkapkan hal yang sama:

Tapi, kalau aku pribadi sih kalau lagi daurah, emang dipanjangin, sengaja, kalau lagi biasa ya seenak hati aja... soalnya itu (ketika lagi daurah) kan interaksinya intensif juga kan, (seperti) ikhwan akhwat terus ama peserta juga, buat lebih menjaga aja. ${ }^{35}$

Berbeda dengan hal tersebut, kader KMNU lebih memandang jilbab secara kultural. Salah satu informan menceritakan bahwa ketika pada acara-acara diskusi ataupun acara-acara rutin berkala, anggota KMNU lebih beragam, ada yang pakai jilbab kecil, panjang, besar sampai menutup tangan, bahkan ada yang bercadar. Keberagaman dan keberbedaan pakaian tersebut menunjukkan bahwa tidak ada aturan secara khusus bagi KMNU dalam persoalan jilbab, dan masing-masing individu secara bebas mengekspresikan keinginannya dalam berjilbab. Keberbedaan tersebut juga tidak menjadikan seluruh anggota merasa bahwa itu harus diseragamkan, mereka cenderung lebih terbuka terhadap hal yang baru dan berbeda. ${ }^{36}$

Beberapa hal di atas menunjukkan bahwa jilbab bagi organisasi Islam di kampus mempunyai keberbedaan dalam pemakaian seharihari dan pemakaian dalam acara-acara resmi organisasi yang menunjukkan loyalitas terhadap organisasi yang diikuti, kecuali bagi KMNU yang bersikap lebih menyerahkan seluruh keinginan dan kenyamanan bagi pengguna jilbab tersebut.

Sampai di sini, agaknya kader-kader KMNU lebih cenderung membebaskan kader-

34 Ay (Mahasiswi jurusan Agrobisnis Ekonomi Pertanian UGM kader IMM) wawancara oleh Qowim, pada 12 September 2017.

${ }^{35} \mathrm{Fi}$ (Mahasiswai jurusan Geografi UGM kader KAMMI) wawancara oleh Qowim, pada 9 September 2017.

${ }^{36}$ Di (Mahasiswi Pertanian UGM kader KMNU) wawancara oleh Qowim, pada 19 September 2017. nya dari belenggu-belenggu doktrin yang justeru, menurut pandangan penulis lebih bersifat membebaskan -untuk tidak mengatakan apatis - terhadap persoalan jilbab bagi kadernya, sebab tidak ada upaya secara terstruktur atau kultural dengan melakukan pendekatan persuasif terkait penggunaan jilbab yang "benar" di lingkungan KMNU. Hal ini berbeda dengan kader-kader IMM dan KAMMI, meskipun tidak ada upaya struktural-instruktif terkait jilbab, biasanya senior-senior mereka melakukan pendekatan terhadap kader yang jilbabnya belum memenuhi standard jilbab "yang benar".

Menurut penulis, hal tersebut tidak kemudian menyatakan bahwa KMNU tidak peduli terhadap anggotanya, sedangkan IMM dan KAMMI peduli sekaligus bertanggung jawab terhadap kadernya, namun KMNU lebih membiarkan kadernya untuk mencari sendiri "kebenaran" yang dilaluinya dengan berproses secara mandiri. Sedangkan IMM dan KAMMI lebih mengarahkan kadernya dalam menemukan "kebenaran" tersebut. Meski demikian, ketiga organisasi tersebut telah memberikan petunjuk yang kuat bahwa proses dalam berjilbab adalah keniscayaan perkembangan keimanan terhadap agama Islam.

Dengan demikian, penemuan identitas diri sebagai bagian dari kelompok/organisasi tertentu tidak dilakukan secara instan, melainkan butuh proses panjang dengan memahami, memroyeksikan diri, refleksi, internalisasi sekaligus komitmen terhadap kebenaran yang diyakininya baik secara subyektif, maupun secara kelompok.

\section{SIMPULAN}

Penggunaan jilbab adalah realitas sosial yang permasalahannya sangat kompleks, tidak hanya persoalan teologis, tetapi juga persoalan perkembangan sekaligus pencarian jati diri, yang mempertimbangkan aspek kenyamanan dan keamanan bagi pemakai jilbab itu sendiri, meskipun aspek tersebut juga terpengaruh oleh lingkungan sosial yang melingkupinya. Pengaruh sosial dalam hal ini sangat variatif, di antaranya diperoleh dari lingkungan keluar- 
ga, teman, dan organisasi Islam yang diikuti di kampus.

Pengaruh organisasi, dalam hal ini KAMMI, IMM dan KMNU, memberikan pengaruh yang signifikan terhadap model dan karakter berjilbab bagi masing-masing kadernya, kendati mempunyai cara yang berbedabeda dalam memberikan pengawalan anggotanya. Meski demikian, tidak menutup kemungkinan bahwa karakteristik dan pergantian dari berbagai macam model jilbab merupakan keniscayaan yang terjadi pada usia-usia sebelum 20 tahun. Sebab usia sebelum itu secara psikologis mulai mencoba dan mengembangkan pemikiran operasional formal dan mulai mengintegrasikan hal-hal yang mereka pelajari mengenai agama ke dalam sistem kepercayaan yang koheren. Hal itulah bagian dari cara individu dalam membentuk identitasnya.

Dari studi ini, sebagaimana mengikuti teori identitas Berger, organisasi mahasiswa Islam di UGM baik KAMMI, IMM, maupun KMNU secara formal tidak memberikan strandardisasi model jilbab yang spesifik, melainkan secara umum bahwa yang terpenting adalah menutupi dada. Meski demikian terdapat semacam norma tak tertulis yang menjadi kesepakatan bersama bahwa dalam kegiatan organisasi, para anggota akan datang dengan mengenakan jilbab yang sesuai dengan standard norma tak tertulis tersebut, terutama bagi organisasi KAMMI dan IMM. Berbeda dengan hal tersebut, KMNU dari awal secara lebih terbuka membebaskan kadernya untuk memakai jilbab yang sesuai dengan keinginan dan kenyamanannya dengan menyadari bahwa jilbab adalah persoalan pencarian jati diri.

\section{DAFTAR PUSTAKA}

Ahmadi, Dadi, dan Nova Yohana. "Konstruksi Jilbab sebagai Simbol Keislaman." MediaTor (Jurnal Komunikasi) 8, no. 2 (29 Desember 2007): 235-48. http://ejournal.unisba.ac.id/index.php/media tor/article/view/1155.

Al-Qurtubi, Syamsuddin. Tafsir al-Qurthubi. t.k.: Maktabah Syamela, t.th.

Amin, Qasim. Tahriru al-Mar'ah. Mesir: Zaky ad-Din, $1347 \mathrm{H}$.
At-Thabari, Muhammad Ibn Jarir. Jami'ul Bayan fi Ta'wil al-Qur'an. Vol. 20. Beirut: Muassasati ar-Risalah, 2000.

Berger, Peter. Tafsir Sosial Atas Kenyataan: Risalah Tentang Sosiologi Pengetahuan. Jakarta: LP3ES, 2013.

Fathoni, Farid. Kelahiran yang Dipersoalkan: Seperempat Abad Ikatan Mahasiswa Muhammadiyah (IMM) 1964-1989. Jakarta: Bina Ilmu, 1990.

Guindi, Fedwa El. Jilbab: Antara Kesalehan, Kesopanan dan Perlawanan. Jakarta: Serambi Ilmu Semesta, 2004.

Jannah, Anas Shoffa'aul. "Konstruksi Identitas Kolektif Perempuan Gerakan Salaf (Studi di Masjid Ibnu Sina Fakultas Kedokteran UGM Yogyakarta)." Jurnal Sosiologi Agama 5, no. 2 (2013): 41-54. http://ejournal.uin-

suka.ac.id/ushuluddin/SosiologiAgama/arti cle/view/1177.

Juneman. Psychology of Fashion: Fenomena Perempuan [melepas] jilbab,. Yogyakarta: Pustaka Pelajar, 2011.

Katsir, Ibnu. Tafsir al-Qur'an al- 'Adhim. t.k.: Maktabah Syamela, t.th.

Machmudi, Yon. Islamising Indonesia: The Rise of Jemaah Tarbiyah and The Prospereous Justice Party (PKS). Canberra: Australian National University Press, 2008.

Pjiper, G.F. Beberapa Studi Tentang Sejarah Islam di Indonesia 1900-1950. Diterjemahkan oleh Yessy Augusdin Tudjimah. Jakarta: Universitas Indonesia, 1984.

Ramadhini, Eveline. "Jilbab sebagai Representasi Simbolik Mahasiswi Muslim di Universitas Indonesia." MASYARAKAT: Jurnal Sosiologi 22, no. 1 (28 Januari 2017): 81-103. doi:10.7454/mjs.v22i1.6835.

Risnayanti, Besse, dan Hafied Cangara. "Jilbab sebagai Simbol Komunikasi di Kalangan Mahasiswa Universitas Hasanuddin (Studi Komunikasi Nonverbal).” Jurnal Kareba 1, no. 2 (2011).

Shihab, Quraish. Jilbab Pakaian Wanita Muslimah: Pandangan Ulama Masa Lalu 
dan Cendekiawan Kontemporer. Jakarta: Lentera Hati, 2014.

Smith-Hefner, Nancy J. "Javanese Women and the Veil in Post-Soeharto Indonesia." The Journal of Asian Studies 66, no. 2 (26 Mei 2007): 389-420. doi:10.1017/S0021911807000575.

Syahrur, Muhammad. Nahwa Ushul Jadidah Li al-Fiqh al-Islam. Beirut: al-Hali, 2002.

Turmudi, Endang. "The Passion of Jilbab: Socio-Cultural Transformation of Indonesian Muslim Women." International Journal of Scientific and Research Publications 6, no. 5 (2016): 287-92.

\section{WAWANCARA}

Di, (Mahasiswi Pertanian UGM anggota KMNU)wawancara pada Sabtu, 9 September 2017 di Sekretariat KMNU Pogung Sleman.
Fi, (Mahasiswi Jurusan Geografi UGM anggota KAMMI),wawancara pada Sabtu, 9 September 2017 di Perpustakaan UGM.

Fir, (Mahasiswi UGM anggota KMNU) wawancara pada Sabtu, 9 September 2017 di Sekretariat KMNU Pogung Sleman.

$\mathrm{Ni}$, (Mahasiswi Jurusan Psikologi anggota KAMMI),wawancara pada Sabtu, 9 September 2017 di Perpustakaan UGM.

$\mathrm{Nu}$, (Mahasiswi Jurusan Ilmu Komunikasi Anggota KAMMI), wawancara pada Senin, 11 September 2017 di Perpustakaan UGM.

Pri, (Mahasiswi Sastra Arab UGM anggota KMNU)wawancara pada Sabtu, 9 September 2017 di Sekretariat KMNU Pogung Sleman/ 